\title{
Are we facing NOVICHOK nerve agent threat?
}

\author{
Kamil Kuca, ${ }^{1}$ Eugenie Nepovimova ${ }^{2}$
}

1. Philosophical Faculty, University of Hradec Kralove, Hradec Kralove, Czech Republic

2. Department of Chemistry, Faculty of Science, University of Hradec Kralove, Hradec Kralove,

Czech Republic

\section{SHORT COMMUNICATION}

Please cite this paper as: Kuca K, Nepovimova E. Are we facing NOVICHOK nerve agent threat? AMJ 2019;12(2):49-52.

https://doi.org/10.21767/AMJ.2018.3482

\section{Corresponding Author:}

Kamil Kuca

Philosophical Faculty, University of Hradec Kralove, Hradec Kralove, Czech Republic

Email: kamil.kuca@uhk.cz

In the short history, at least four similar attacks by nerve agents were committed. In this short communication, we wanted to interlink some important insights into nerve agents and novichoks and point out that the latest assault by novichoks is not the only attack with prohibited chemical warfare agents and, unfortunately, probably not the last, as these substances can easily be synthesized in a well-equipped chemical laboratory.

$4^{\text {th }}$ March 2018, ex-Russian spy Sergey Skripal and his daughter were found on a bench in the park close to the shopping centre in Salisbury (UK). According to the first onsite examination and the symptoms, it was obvious that they were highly likely poisoned by a nerve agent. Subsequent sampling and closer examination of both victims confirmed this fact. The most likely substance that caused the poisoning of both victims was Novichok (Newcomer; in Russian language "новичок"). This substance belongs to the "hypothetical" chemical warfare agents of the former Soviet Union. Why hypothetical? Because it has never been officially confirmed for its introduction into the armament. Therefore, this substance has never been on the official list of banned chemical warfare agents. Not only the substance itself but also its possible precursors are missing on this list. Based on all mentioned above, it can be de facto freely synthesized and tested. ${ }^{1,2,3}$
A very similar incident to that of Skripal happened last year (2017) at the airport in Kuala Lumpur (Malaysia), when a nerve agent was also used - this time the VX agent. The victim was a half-brother of the Korean nation's leader Kim Jong Un - Kim Jong Nam. It has been confirmed that two women splashed a victim with a nerve agent, which subsequently died.,4

Although these two incidents are probably two the most popular in the media, other inconvenient people were attacked in the same way in the past. For example - the attack of a secret agent in the sect, who investigated the Aum Shinrikyo, using the VX agent (Osaka, Japan, 1994), or the attack on Russian banker Ivan Kivelidi and his secretary probably also by an analogue of VX agent (Moscow, Russia, 1995). ${ }^{5,6}$

In the 1970 s up to the 1990 s, chemical warfare agents, especially nerve agents, were an alternative to nuclear weapons. They were even called the "nuclear weapons of the poor countries" since the synthesis was relatively simple and easy for upscaling amounts as well as their effect was terrible. Comparing chemical warfare agents with biological or radiological, the rapid onset of their effect is the reason of their choice by the terrorists. Just a few minutes after intoxication, the affected person dies on site of contamination, possibly in the immediate vicinity. Terrorism is now largely interconnected with the media. From the definition of the word - terrorism - it is clear that it is violence or a threat of violence in order to intimidate the enemy and reach the political goals. What is better than frighten people using videos where the victims of such attacks are writhing in non-physiological convulsions, uncontrollably lying on the ground with foam at the mouth etc.?!

In case of biological attack, de facto viral or bacterial diseases with high lethality, clinical manifestation of intoxication always occurs after a period of latency. Moreover, it is characterized by the onset of a disease 
that within the first phase renders the symptoms of influenza or other common diseases. The victim finally dies, but in the building of the hospital, where the patients are dying normally. Similarly, Russian journalist Litvinenko (London, UK, 2006) died in hospital three weeks after the poisoning with radioactive polonium 210 . This murder could be considered as a terroristic attack with a radiological weapon. ${ }^{7}$

Of course, we do not want to make light of the severity of biological or radiological weapons. With regard to the type of chemical warfare agent, its effectiveness and spreading intimidation, it seems to be the most probable abuse of chemical warfare agent, as witnessed by two recent attacks in Malaysia and the UK.,

What do we know about the Novichok till now?

Novichok is not a single substance - one derivative. According to the available data, there are at least two groups of substances differing in the basic chemical structure. Their existence became known to the world thanks to the Russian scientist Dr. Mirzianov, who defected from the Soviet Union and published one of the possible structures in 1992. Subsequently, unofficial/hypothetical structures known as possible novichok-candidates have been published (Figure 1). ${ }^{8-11}$

Figure 1: Chemical structures of sarin, VX agent, proposed general structure of Novichoks, and commercially available AChE reactivators<smiles>CC(C)OP(C)(=O)F</smiles>

Sarin

$\mathrm{Cl}^{-} \stackrel{\mathrm{I}}{\mathrm{C}} \mathrm{H}_{3}$

Pralidoxime<smiles>ON=Cc1ccccn1</smiles>

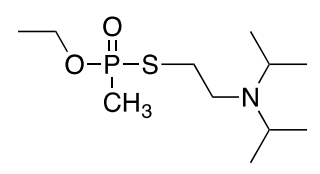

VX agent

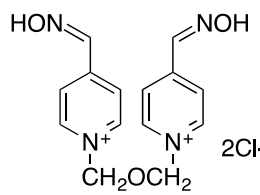

Obidoxime<smiles>[R]C([R])=NOP(=O)(F)OC([R3])C([R3])Cl</smiles>

Novichoks

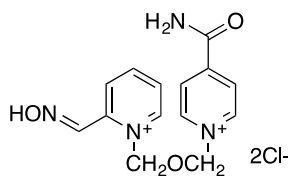

Asoxime
As mentioned above, this group of substances belong among the nerve agents. Their effect is therefore similar to that of sarin, soman or VX agent - inhibition of the enzyme acetolycholinesterase (AChE), overstimulation of nicotinic and muscarinic receptors and the subsequent cholinergic crisis resulting in death of the intoxicated organism. The detailed symptoms of intoxication caused by nerve agents can unfortunately be seen even on Youtube due to their recent misuse in Syria (2013). ${ }^{12}$

It could be expected that in the case of novichok intoxication, its treatment would involve the same approaches as for nerve agents, however, only partially. As we know, nerve agent treatment consists of anticholinergics and anticonvulsants, which are used only as symptomatic treatment. In the case of nerve agent or organophosphorus pesticide poisoning, also AChE reactivators are used as a causal treatment. They restore the function of inhibited AChE. Pralidoxime (commercially available in the USA), obidoxime (used mostly in the EU) or asoxime (probably the most effective but currently not commercially available by any pharma company) belong among the most important AChE reactivators. Unfortunately, none of these antidotes represents an universal antidote that can cause the causal effects on all types of nerve agents. ${ }^{13}$

With regard to the mode of action of AChE reactivators, it is believed that novichoks have been developed so that AChE reactivators do not work. The chemical structure of novichoks is very similar to the structure of adducts that arise when oximes are reactivating the AChE - the socalled phosphorylated oximes, which is very toxic. Moreover, conjugate Novichok-enzyme quickly dealkylates (such process is known as aging of the inhibited enzyme), thereafter reactivation of the enzyme is no more possible (Figure 2). ${ }^{11,14,15}$

Therefore, only symptomatic treatment in combination with oxygen therapy and support for the maintenance of life functions can be recommended as a possible treatment. Other possible therapies could be BuChE bioscavengers which were originally developed as prophylaxis against the nerve agents. This type of prophylaxis has been developed as a possible therapeutics given to special units or individuals most likely to those present in the hot zone and/or coming in contact with nerve agents. Bioscavengers bind nerve agent detoxifying it prior it reaches the target organ. The use of bioscavenger as an ex-post treatment should help to detoxify free not yet reacted novichoks in the blood stream and so reduce their toxic effect. ${ }^{16}$

In this short communication, we wanted to interlink some important insights into nerve agents and novichoks and point out that the latest assault by novichoks is not the only attack with prohibited chemical warfare agents and, 
unfortunately, probably not the last, as these substances can easily be synthesized in a well-equipped chemical laboratory. In addition, there is no need for an extra-large amount of this substance, the teaspoon of this agent (if well distributed) will be sufficient to kill lots of people.

\section{References}

1. Roth A, McCarthy T. 'It's got me': the lonely death of the Soviet scientist poisoned by novichok. The Guardian. 2018.

2. Organisation for the Prohibition of Chemical Weapons, (available at https://www.opcw.org/).

3. Nepovimova E, Kuca K. The history of poisoning: from ancient times until modern ERA. Arch Toxicol. 2019; 93(1):11-24.

4. Zhen W. Kim Jong-nam killed by VX nerve agent, say Malaysian police. The Guardian. 2017.

5. Zurer P. Japanese cult used VX to slay member. Chem Eng News. 1998;76:7.

6. Roth A. Nerve agent was used in 1995 murder, claims former Soviet scientist. The Guardian. 2018.

7. Cobain I. Poisoned former KGB man dies in hospital. The Guardian. 2006

8. Hoenig SL. Compendium of Chemical Warfare Agents (Springer-Verlag, New York, 2007; www.springer.com/us/book/9780387346267).

9. Ellison HD. Handbook of Chemical and Biological Warfare Agents. CRC Press (2007), (available at https://www.crcpress.com/Handbook-of-Chemical-andBiological-Warfare-Agents-SecondEdition/Ellison/p/book/9780849314346).

10. Mirzayanov VS. State Secrets: An Insider's Chronicle of the Russian Chemical Weapons Program (Outskirts Press, Incorporated, 2009).

11. Nepovimova E, Kuca K. Chemical warfare agent NOVICHOK - mini-review of available data. Food Chem Toxicol. 2018; 121:343-350.

12. Rosman $\mathrm{Y}$, Eisenkraft A, Milk $N$, et al. Lessons learned from the Syrian sarin attack: evaluation of a clinical syndrome through social media. Ann Intern Med. 2014;160:644-648.

13. Gorecki L, Korabecny J, Musilek K, et al. SAR study to find optimal cholinesterase reactivator against organophosphorous nerve agents and pesticides. Arch Toxicol. 2016;90:2831-2859.

14. Halamek E, Kobliha Z. Potential Chemical Warfare Agents. Chem Listy. 2011;105:323-333.

15. Leader $H$, Vincze A, Manisterski $B$, et al. Characterization of O,O-diethylphosphoryl oximes as inhibitors of cholinesterases and substrates of phosphotriesterases. Biochem Pharmacol. 1999;58:503-515.

16. Bajgar J, Fusek J, Kassa J, et al. Chemical aspects of pharmacological prophylaxis against nerve agent poisoning. Curr Med Chem. 2009;16:2977-2986.

\section{PEER REVIEW}

Peer reviewed.

\section{CONFLICTS OF INTEREST}

The authors declare that they have no competing interests.

\section{FUNDING}

This work was supported by the Long-term development plan UHK. 
Figure 2: Mechanism of AChE inhibition by Novichoks, suggested aging and reactivation by AChE reactivators (Ref. 11)

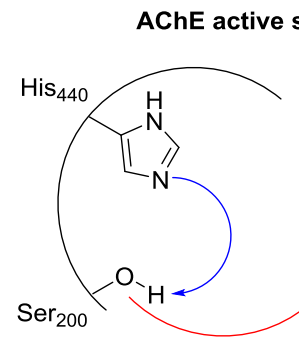

active enzyme

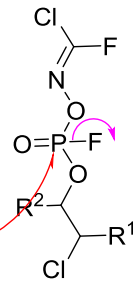

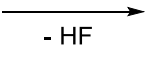

AChE active site

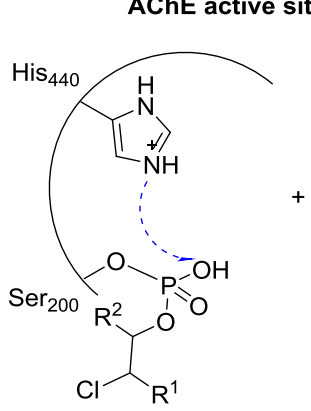

aged enzyme

AChE active site

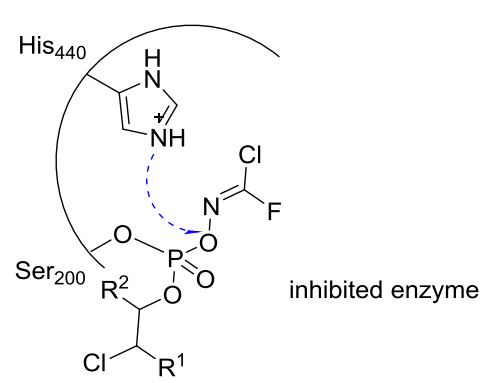

$\overbrace{\mathrm{Cl}}^{\mathrm{HO}}$
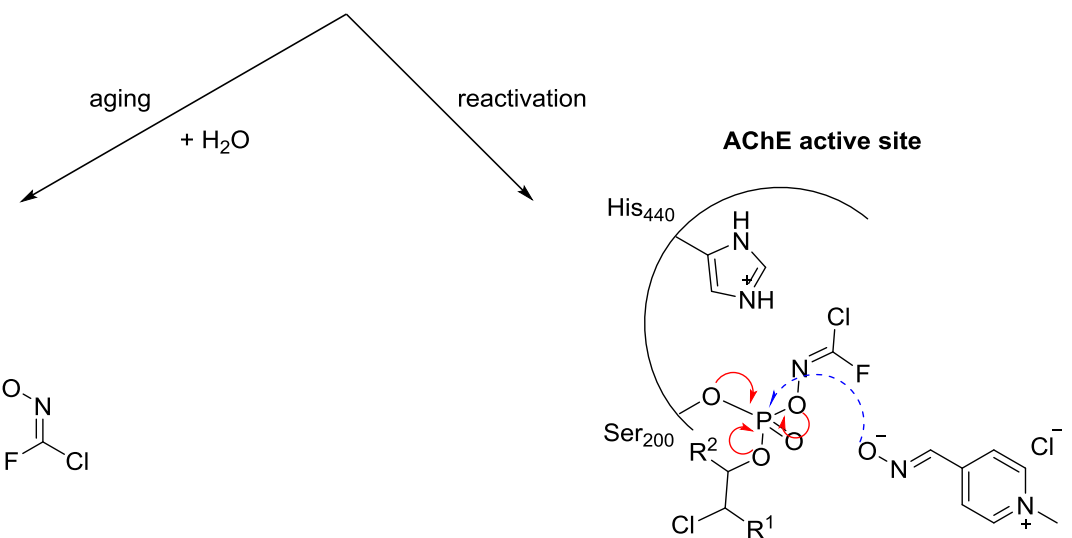

poorly reactivable enzyme 